\title{
THE NATURAL HUMAN RIGHT TO SECURITY AND SECURITY AS A CONSTITUTIONAL HUMAN RIGHT
}

\section{Introduction}

This article is devoted to the memory of Dr. Kinga Stasiak, with whom I had the honour and pleasure to work at the Faculty of Law, Canon Law and Administration of the John Paul II Catholic University of Lublin. We wrote an article together Mortui vivos docent. In Memory of Rev. Professor Antoni Kość, SVD, (Review of Comparative Law 2012, vol. 17). Although a year has passed since the death of Dr. Kinga Stasiak, it is still difficult to come to terms with writing about her in the past tense. 'The one who lives in the memory of others does not die' - in this sense Dr. Kinga Stasiak is still present.

Both in her scientific work and in interpersonal contacts, human and his or her subjective rights were important to Dr. Kinga Stasiak. Referring to this, in this article I formulate the thesis on the existence of a natural human right to security, and subsequently I analyse the issue of the relationship between the natural human right to security and security as a constitutional human right. The primary objective of the research is to answer the question: Does the natural human right to security influence the existence of security as a human right, guaranteed by positive law, in particular in constitutional law?

* Dr. habil., Associate Professor the John Paul II Catholic University of Lublin, e-mail: jadwiga.potrzeszcz@kul.pl, https:/ / orcid.org/0000-0002-4358-7273. 


\section{Relation of concepts: 'natural law' - 'human law'}

When considering the issue of human rights in the perspective of natural law, we should first consider the relationship between the concept of 'natural law' and the concept of 'human law'.

Hanna Waśkiewicz distinguished the inextricable link between human rights and natural law. She defined human rights as a special type of subjective rights, i.e. rights of a legal nature which are entitled to man by virtue of natural law. ${ }^{1}$

Similarly, Arthur F. Utz, when considering the issue of the legal natural content of human rights, defines human rights as natural rights of the individual included in legal principles. According to Utz, when formulating human rights, we determine positively applicable legal principles. Human rights are derived from human nature and formulated directly for the practical support of social life, the principles in which universal norms arising from human social nature are transformed. Thereby they are not unlike the sentence: 'do good, avoid evil' - directly obvious, but they must be inferred through practical reason from the nature of the individual and society. In this case, we cannot overlook that practical reason is always rooted in a specific, historical and cultural connection. Human rights as specific subjective rights of individuals must be understood as results of natural thinking formed by culture. Although this does not indicate that the formulation of human rights represents only historical randomness or is created by certain decision of the states, but it explains that the understanding and actual recognition of human rights had yet to develop in the course of history of mankind. ${ }^{2}$

The placement of human rights in positive law is essential to guarantee their legal binding force, i.e. their real feasibility of implementation. On the other hand, this does not mean that crimes against human rights would be legally prosecuted if they had already been included in the form of positive law. When a society once passed through the stage of culture that corresponds to natural laws, we must expect every individual to recognize a serious violation of human rights as striking human nature.

1 H. Waśkiewicz, Prawa człowieka a prawa rodziny, Chrześcijanin w Świecie 1985, No 4 (139), p. 30.

2 A.F. Utz, Begriff und Wesen der Menschenrechte, in: Ethik des Gemeinwohls. Gesammelte Aufsätze 1983-1997, ed. W. Ockenfels, Paderborn-München-Wien-Zürich 1998, p. 71. 
Human rights are applicable legal order principles. According to their nature, they should be placed immediately before the constitution as the guiding principles of the authority creating it. As such, they offer the basis for examining the constitution and simple laws when it comes to their legal nature, i.e. preserving directly with the notion of law minimum moral demands in relation to the law. ${ }^{3}$

Creating positive laws primarily serves to guarantee legal security. Thus, human rights that are directly binding on the legislator must be included in the form of positive law by the legislator so that they are guaranteed real effectiveness in everyday life. On the other hand, we must interpret laws in accordance with the basic norms of the state, in accordance with the constitution, and thus also in accordance with the human rights contained therein which are of primary importance to them. The fact that human rights can in principle be used by any person in relation to every person, does not result in any case, within the meaning of the natural social order, that we should leave the judge an interpretation of human rights regardless of legal security. In this case, legal security also takes precedence over individual and legal reasons, because it has elementary significance for the state of legal order in general and thus for the entire social order. This example proves clearly that the subjective and legal positions derived from human rights must always harmonize with the order of society as a whole. However, the legislator is obliged to include natural laws in the form of positive laws as completely as possible in order to avoid the law-making activity of judges. ${ }^{4}$

Every legal order must be able to legitimize. The legitimisation of an existing positive legal order must prove that it corresponds to human nature, because the social order must be marked as just. Only in this manner we transcend the fact, i.e. the existing order, if its measurement is based on human nature, i.e. on the basis of the principles of activity which stem from the human nature and consequently natural law in the first place is the norm of a just social order. ${ }^{5}$

Currently, such a relationship of interdependence between human rights and natural law, unfortunately, is no longer so widely recognized and one can observe the process of distancing these phenomena.

3 Ibidem, pp. 71-72.

$4 \quad$ Ibidem, p. 72.

5 A.F. Utz, Die Grundpositionen der Naturrechtstheorien, in: Ethik des Gemeinwohls..., p. 59. 
In other terms, in contemporary social reality human rights are formulated without reference to the base of natural law. A detailed analysis of this process requires a separate study, because it is beyond the scope of this research work.

To sum up this part of the discussion, we turn our attention to the differences between the concept of human rights and the concept of natural law. Undoubtedly, natural law is an unwritten law, resulting from the very human nature. While human rights are most often understood as written laws, declared in a normative act, whether of international law, European Union law or the constitution. In this study, the provisions of the Polish Constitution will be particularly emphasized. ${ }^{6}$

In connection with the adopted research objective, our attention will be focused on one of the human rights, namely security as a human right. The concept of security as a human right will be understood as a constitutional human right to security. In contrast, the natural human right to security will be understood as the right arising from human very nature and needs having its basis in this nature.

In view of these basic assumptions, the primary thesis defended in this article reads as follows: a human being has a natural right to security, however, security as a human right was not explicitly expressed in the Constitution of the Republic of Poland. The question therefore arises, whether it is possible, under the constitutional provisions, to separate such a human right. Before attempting to answer this question, the very notion of security in the context of human rights should be clarified.

\section{The concept of security in relation to human}

In a general sense, security is the opposite of danger and it means freedom from threats. There are many detailed definitions of security that cannot be analysed here due to the framework of this study. It is worth emphasizing that security is a very important human need located on the border of biological and psychological needs. According to the wellknown view of Abraham $\mathrm{H}$. Maslow, people are motivated in their activity

6 Konstytucja Rzeczypospolitej Polskiej z dnia 2 kwietnia 1997 r. (Dz. U. Nr 78, poz. 483 z późn. zm.). 
through a hierarchical system of basic needs that originate from instincts. Essentially lower needs in the hierarchy dominate and win in conflict with the higher ones. ${ }^{7}$

The lowest in the hierarchy are physiological needs (hunger, thirst, sexual needs). Above them are the needs of security (certainty, stability, dependence, care, freedom from fear, anxiety and chaos, the need for order and law, restrictions, a strong guardian). At the next level, there are needs for affiliation (love, tenderness, belonging). After satisfying them, the needs of respect, achievement and prestige are revealed. That man was able to realize himself, he or she must satisfy before all of the above-mentioned needs, by Maslow called deficiency needs. Only then does the need for self-realization come into play - the only need for development. According to the author, "man must be who he can be, he must be faithful to his nature". It does not often occur that an individual is able to fully satisfy this need. The pursuit of self-realization, however, gives meaning to human life. ${ }^{8}$

In A.H. Maslow's theory of needs, satisfying the necessity of security is classified as one of the fundamental needs, without which an individual cannot satisfy other needs, such as the need for group unity, respect and self-fulfilment. ${ }^{9}$ Therefore, the necessity of security is of paramount importance in relation to other needs. Its dissatisfaction prevents normal, uninterrupted fulfilment of higher needs (social, ego, self-fulfilment). ${ }^{10}$

The necessity of security includes three categories of elements: 1) enabling the survival needs, 2) protection of property acquired by man, 3) desire for order, confidence in life, predictability of events and behaviour of other people. ${ }^{11}$ Human nature is something universal that does not exist as such and can always be recognized in individual beings. However, in

7 A. Maslow, Motywacja i osobowość, transl. J. Radzicki, Warszawa 2006, pp. 115-122; see: idem, A Theory of Human Motivation, Psychological Review 1943, pp. 370-396.

9 W. Gizicki, Bezpieczeństwo jako proces polityczno-społeczny, in: Społeczno-moralna potrzeba bezpieczeństwa i porządku publicznego, eds. J. Świtka, M. Kuć, G. Gozdór, Lublin 2007, p. 18.

10 J. Guść, Ład społeczny, poczucie bezpieczeństwa a prawo - kilka uwag z zakresu teorii prawa, in: Problemy bezpieczeństwa prawnego z perspektywy teorii i filozofii prawa. Tom dedykowany prof. zw. dr. hab. Tomaszowi Langerowi z okazji 40-lecia pracy zawodowej i 30-lecia kierowania zespołowa Katedra Teorii Państwa i Prawa Wydziału Prawa i Administracji Uniwersytetu Gdańskiego, eds. J. Jabłońska-Bonca, J. Guść, „Gdańskie Studia Prawnicze” 2002, vol. 9, p. 15.

11 Lexikon der Psychologie, eds. W. Arnold, H.J. Eysenck, R. Meili, ed. 3, Freiburg-Basel-Wien 1972, pp. 325-326. 
this manner we encounter the difficulty in how we should explain what is common in relation to the plurality and diversity of individual beings as an independent reality from our consciousness. We would not be able to discuss human rights if there was not one significant feature in a human being that belongs to all individuals equally. ${ }^{12}$

Throughout their history, human rights originated from human awareness and articulation of needs, afterwards normative-making of them, and thus their legal protection, and subsequently attempts to make them the most effective. Throughout their history human rights 'were thought in categories of needs', and they in their historical dynamics developed and enriched, proving evolution and generally progress. ${ }^{13}$

Therefore, the fact that man has in his nature a deeply rooted necessity of security, which he realizes at the moment of activation of a threat, whether regarding his basic life goods or his interests and related development opportunities, justifies the existence of the natural human right to security.

\section{The natural human right to security}

The natural right of man to security includes both security in a subjective sense and security in an objective sense. Security in the subjective sense is a human mental state, meaning freedom from a sense of insecurity, introduces mental balance, increases activity and determines development of the personality. Whereas security in the objective sense means the set of physical and social conditions that ensure the maintenance and relative durability of human life and his development. ${ }^{14}$

Referring to security as a value, the question arises whether it is an intrinsic or instrumental value. Undoubtedly, the latter term should be indicated. Security as such is not an intrinsic value, it is not an end in itself.

12 A.F. Utz, Die menschliche Natur als Grundlage der Sittlichkeit, in: Ethik des Gemeinwohls..., p. 15.

13 T. Jasudowicz, Potrzeby jako wspótczesny determinant treści praw człowieka, in: Potrzeby jako wspótczesny determinant treści praw człowieka, eds. E. Ura, B. Sitek, T. Graca, Józefów 2017, p. 7.

14 Z. Chlewiński, Bezpieczeństwo, in: Encyklopedia Katolicka, vol. 2, eds. F. Gryglewicz, R. Łukaszczyk, Z. Sułowski, Lublin 1995, col. 347. 
Justification of its existence security gains only in consequence of other values and goods which it serves to protect. Sustaining the existence, properties and functions of various goods, it sustains ipso facto the existence of the values which they are entitled. Protecting man, his natural and cultural environment, they conducive to their survival, prolong their existence, prevent degradation and annihilation. ${ }^{15}$

It is worth emphasizing that when we discuss the natural right of man to security, we have in mind not only the sense of human security, but primarily security in its objective sense. The natural human right to security in the objective sense denotes his right to protection regardless of the state or of his development and his consciousness. The life goods of the man and his interests are to be protected adequately to who the man is - undoubtedly a spiritual and bodily being. Therefore, the first fundamental goods of man, without which other goods would have no justification, are his life and health, and subsequently numerous other goods and interests significant not only to his survival but also to human development.

\section{Security as a constitutional human right}

The author of this article is convinced that man has the natural right to security. However, the question arises whether this natural right is reflected in the provisions of the Constitution. In other words, we can raise the question whether and to what extent man has his subjective right to protection by the state. In a democratic state of law, ensuring the protection of individual freedoms and rights by the public authority consists in granting qualified entities legally defined measures that will serve the broadly understood protection of goods. Public expectations revolve around the sense of security, safeguarding the interests, the absence of invasion of privacy and non-infringement of freedom and personal inviolability, including personal security. Security, as a certain condition that provides an individual with a sense of certainty in the elementary value

15 A. Węgrzecki, Ontologiczne i aksjologiczne aspekty bezpieczeństwa, in: Bezpieczeństwo jako wartość, Kraków 2010, pp. 23-24. 
of being, and a guarantee of preservation and continuity of its existence, enables its further development and improvement. ${ }^{16}$

There is an anxiety that the separation of the fundamental human right to security could arouse excessive expectations of citizens that state authorities would not be able to manage. Regardless of these concerns and doubts, it should be emphasized that the duty of the state towards all people living on its territory not only is to ensure freedom, but also to protect against threats, i.e. to ensure security. In this sense, ensuring security denotes protecting people against other people's attacks, against technical threats, or social security. Despite the variability of goods subject to legal protection, dependent on the will of the legislator, we can indicate inviolable goods subject to protection, namely life, personal inviolability, freedom and property. The natural human right to security is actualized through the detail separated various fundamental rights, which are designed to protect individual values related to human life and personal development. In the hierarchy of these values at the very top there is a guarantee of respect for and protection of the inherent and inalienable human dignity (article 30 of the Polish Constitution). For instance, we can specify other expressly stated in the Constitution of the Republic of Poland human rights, of which the meaning and function is to provide human security, inter alia, such as: protection of life and health of every human being (art. 38, art. 68), protection of freedom and personal inviolability (art. 31 paragraph. 1, art. 41), prohibition of discrimination (art. 32, paragraph. 2), the citizen's right to protection by the State during a stay abroad (art. 36), prohibition of scientific experiments on people without their voluntary consent (art. 39), prohibition of torture or cruel, inhuman or degrading treatment or punishment (art. 40), the right to defence in criminal proceedings, the presumption of innocence (art. 42), the right to a court (art. 45), the right to legal protection of privacy (art. 47), inviolability of the home (art. 50), the right to protection of personal data (art. 51), the right to ownership, other property rights and the right of succession (art. 64), the right to safe and healthy working conditions (art. 66 paragraph. 1), the right to social security (art. 67), the right of the family to special assistance from public authorities (art. 71), protection of the rights of the child (art. 72),

16 M. Ławrynowicz-Mikłaszewicz, Bezpieczeństwo jako prawo człowieka w kontekście stosowania środków przymusu bezpośredniego i broni palnej przez uprawnione podmioty, Przegląd Prawniczy, Ekonomiczny i Społeczny 2014, No 4, p. 64. 
ecological security and protection of the environment (art. 74), satisfying the housing needs of citizens (art. 75), protection of consumers, customers, hirers or lessees against activities threatening their health, privacy and safety (art. 76).

Although the human right to security is not expressly stated in the Polish Constitution of 1997, it can be interpreted from the whole constitutional values. It is also achievable to derive the human right to security directly from human dignity regulated in art. 30 of the Polish Constitution, according to which ' $[\mathrm{t}]$ he inherent and inalienable dignity of the person shall constitute a source of freedoms and rights of persons and citizens' ${ }^{17}$

In certain articles of the Polish Constitution, the constitutional legislator used the term 'the security of the citizens' (art. 5 and art. 230 paragraph. 1). The concept of the security of the citizens is defined as 'a state in which there are no threats to the life and health of citizens, along with serious threats to their property' ${ }^{18}$ Undoubtedly, every man, if he is to be treated in accordance with his personal dignity, has the natural right to live in the conditions of security so understood, regardless of the fact of establishing this right by the legislator. The concept of security of the citizens was treated correctly in the legal doctrine as a reference to the wording used in the international law concerning the guarantee of personal security. ${ }^{19}$

The concern for the security of citizens is one of the most significant constitutional principles of a modern state. The protection of fundamental rights by the state also does not raise doubts. Problematic, however, is whether and to what extent the individual has a subjective right to protection by the state. The answer to this question has a paradigmatic significance in determining the relationship between individuals and the state in the order of fundamental rights. ${ }^{20}$ In contemporary discussions, we can find both authoritative confirmation of the right to protection as a fundamental right, as well as overbearing denial of it. ${ }^{21}$ Undoubtedly, how-

17 Cf. J. Potrzeszcz, Bezpieczeństwo prawne z perspektywy filozofii prawa, Lublin 2013, pp. 53-54.

18 K. Wojtyczek, Granice ingerencji ustawodawczej w sfere praw człowieka w Konstytucji RP, Kraków 1999, p. 253.

19 B. Banaszak, Konstytucja Rzeczypospolitej Polskiej. Komentarz, Warszawa 2009, p. 53.

20 G. Robbers, Sicherheit als Menschenrecht. Aspekte der Geschichte, Begründung und Wirkung einer Grundrechtsfunktion, Baden-Baden 1987, p. 13.

${ }^{21}$ Ibidem, p. 15. 
ever, the duty of the state towards all people on its territory is not only to ensure their freedom, but also to protect against threats. ${ }^{22}$ When raising the issue of the existence of the right to security as a human right, we should be aware of any questions about who will bear the costs of ensuring security and whether compensation claims will arise if the state does not follow its duty of protection.

By undertaking the study of the issue of the existence of the subjective right to protection of legal rights by the state, and therefore the human right to security, G. Robbers creatively continues the thought of J. Isensee. He intends to find a principle, a kind of ratio legis, for all fundamental rights, and not to separate a new fundamental right. In his point of view, certain specific content that can be combined with the idea of a human right to security in the order of fundamental rights, the scope and limit of the state's duty of protection are obtainable only through the analysis of individual fundamental rights. Only shared properties combining these rights may constitute a meaningful content of the human right to security. Thus, the human right to security indicates the function of the existing fundamental rights, rather than on a separate law. ${ }^{23}$ The fundamental right to security is, according to G. Robbers, in the light of modern constitutional law, the right of individuals towards the state to demand that the state protect the integrity of its legal rights also against the threats coming not from the state. ${ }^{24}$

Regardless of the concerns raised above, it should be emphasized that the constitutional 'right to security', acts as a magnet that attracts in its field iron filings scattered in various branches of law provisions relevant to human security. ${ }^{25}$ Although the idea of the right to security permeates many detailed regulations, the separation of the human right to security may affect not only the legal system but also the thinking of lawyers. ${ }^{26}$

I argue that the human right to security may be regarded as a type of meta-law, analogously, mutatis mutandis, as the human right to equal treatment. On the basis of the Polish Constitution, this right may be

22 J. Isensee, Das Grundrecht auf Sicherheit. Zu den Schutzpflichten des freiheitlichen Verfassungsstaates, Berlin 1983, pp. 17-18.

${ }^{23}$ G. Robbers, Sicherheit als Menschenrecht..., p. 15.

24 Ibidem, p. 121.

25 J. Czapska, Bezpieczeństwo obywateli. Studium z zakresu polityki prawa, Kraków 2004, pp. 81-82.

${ }^{26}$ J. Potrzeszcz, Bezpieczeństwo prawne z perspektywy filozofii prawa..., p. 53. 
derived primarily from art. 30 of the Constitution, as under that provision ' $\mathrm{t}$ ] he inherent and inalienable dignity of the person shall constitute a source of freedoms and rights of persons and citizens'. Since the catalogue of human rights is not closed, it may be developed and clarified. Although the human right to security is not explicitly expressed in the Polish Constitution, as it was aforementioned, it may be derived from art. 30 of the Constitution. This provision was recognized by the Polish Constitutional Tribunal as a supplementary clause. According to the Constitutional Tribunal, the normative content contained in the concept of human dignity referred to in art. 30 of the Constitution, covers

the most important values that do not benefit from other independent guarantees on a constitutional basis, but which affect the essence of the position of the individual in society, its relationship to other persons and to public authority. ${ }^{27}$

\section{Conclusions}

Considerations carried out in this article allow to draw a few conclusions. First of all, there is no doubt that the man because of his personal dignity and due to its nature, arising from the demand for security, has a natural right to security. The natural right to security means a law that is not enacted in any normative act, it is independent of human regulations. Although the right of every human to security exists in a natural manner, it is important to include this right in the positive law. Only then does the state guarantee its authority to all recipients of the law.

The above analysis of the provisions of the Polish Constitution proved that the right to security as a constitutional human right was not expressly stated in any of these provisions. Certainly, the formulation of an explicit constitutional human right to security raises concerns about the scope of the citizen's ability to enforce this right from the state, e.g. by means of a constitutional complaint. Regardless of the difficulties raised, it is worth interpreting the constitutional human right to security from all the regulations of the Polish Constitution as a function of fundamental rights.

27 See: Wyrok TK z 5 marca 2003 r., sygn. akt K 7/01. 
In justified individual cases of violations, the constitutional human right to security can be derived from art. 30 of the Polish Constitution, which stipulates that the inherent and inalienable dignity of man is the source of his rights and freedoms.

\section{Bibliography}

Banaszak B., Konstytucja Rzeczypospolitej Polskiej. Komentarz, Warszawa 2009.

Chlewiński Z., Bezpieczeństwo, w: Encyklopedia Katolicka, vol. 2, eds. F. Gryglewicz, R. Łukaszczyk, Z. Sułowski, Lublin 1995.

Czapska J., Bezpieczeństwo obywateli. Studium z zakresu polityki prawa, Kraków 2004. Gizicki W., Bezpieczeństwo jako proces polityczno-społeczny, in: Społeczno-moralna potrzeba bezpieczeństwa i porządku publicznego, eds. J. Świtka, M. Kuć, G. Gozdór, Lublin 2007.

Guść J., Ład społeczny, poczucie bezpieczeństwa a prawo - kilka uwag z zakresu teorii prawa, in: Problemy bezpieczeństwa prawnego z perspektywy teorii i filozofii prawa. Tom dedykowany prof. zw. dr. hab. Tomaszowi Langerowi z okazji 40-lecia pracy zawodowej i 30-lecia kierowania zespołowa Katedra Teorii Państwa i Prawa Wydziatu Prawa i Administracji Uniwersytetu Gdańskiego, eds. J. Jabłońska-Bonca, J. Guść, „Gdańskie Studia Prawnicze" 2002, vol. 9.

Isensee J., Das Grundrecht auf Sicherheit. Zu den Schutzpflichten des freiheitlichen Verfassungsstaates, Berlin 1983.

Jasudowicz T., Potrzeby jako współczesny determinant treści praw człowieka, in: Potrzeby jako wspótczesny determinant treści praw człowieka, eds. E. Ura, B. Sitek, T. Graca, Józefów 2017.

Lexikon der Psychologie, eds. W. Arnold, H.J. Eysenck, R. Meili, ed. 3, FreiburgBasel-Wien 1972.

Ławrynowicz-Mikłaszewicz M., Bezpieczeństwo jako prawo człowieka w kontekście stosowania środków przymusu bezpośredniego i broni palnej przez uprawnione podmioty, Przegląd Prawniczy, Ekonomiczny i Społeczny 2014, No 4.

Maslow A., A Theory of Human Motivation, Psychological Review 1943, vol. 50, No 4.

Maslow A., Motywacja i osobowość, transl. J. Radzicki, ed. 2, Warszawa 2006.

Potrzeszcz J., Bezpieczeństwo prawne z perspektywy filozofii prawa, Lublin 2013.

Przetacznik-Gierowska M., Makiełło-Jarża G., Podstawy psychologii ogólnej, Warszawa 1989.

Robbers G., Sicherheit als Menschenrecht. Aspekte der Geschichte, Begründung und Wirkung einer Grundrechtsfunktion, Baden-Baden 1987. 
Utz A.F., Begriff und Wesen der Menschenrechte, in: Ethik des Gemeinwohls. Gesammelte Aufsätze 1983-1997, ed. W. Ockenfels, Paderborn-München-WienZürich 1998.

Utz A.F., Die Grundpositionen der Naturrechtstheorien, in: Ethik des Gemeinwohls. Gesammelte Aufsätze 1983-1997, ed. W. Ockenfels, Paderborn-München-WienZürich 1998.

Utz A.F., Die menschliche Natur als Grundlage der Sittlichkeit, in: Ethik des Gemeinwohls. Gesammelte Aufsätze 1983-1997, ed. W. Ockenfels, Paderborn-MünchenWien-Zürich 1998.

Waśkiewicz H., Prawa człowieka a prawa rodziny, „Chrześcijanin w Świecie” 1985, No 4 (139).

Węgrzecki A., Ontologiczne i aksjologiczne aspekty bezpieczeństwa, w: Bezpieczeństwo jako wartość, Kraków 2010.

Wojtyczek K., Granice ingerencji ustawodawczej w sfere praw człowieka w Konstytucji RP, Kraków 1999.

\section{Sum mary}

In this article it was formulated the thesis on the existence of a natural human right to security, and subsequently the analyse of the issue of the relationship between the natural human right to security and security as a constitutional human right. The primary objective of the research was to answer the question whether the natural human right to security influences the existence of security as a human right, guaranteed by positive law, in particular in constitutional law.

The above analysis of the provisions of the Polish Constitution proved that the right to security as a constitutional human right was not expressly stated in any of these provisions. Certainly, the formulation of an explicit constitutional human right to security raises concerns about the scope of the citizen's ability to enforce this right from the state, e.g. by means of a constitutional complaint.

Regardless of the difficulties raised, it is worth interpreting the constitutional human right to security from all the regulations of the Polish Constitution as a function of fundamental rights. In justified individual cases of violations, the constitutional human right to security may be derived from art. 30 of the Polish Constitution, which stipulates that the inherent and inalienable dignity of man is the source of his rights and freedoms.

Key words: security, natural law, positive law, natural human right to security, constitutional human right to security 


\section{NATURALNE PRAWO CZŁOWIEKA DO BEZPIECZEŃSTWA A BEZPIECZEŃSTWO JAKO KONSTYTUCYJNE PRAWO CZŁOWIEKA}

\section{Streszczenie}

W niniejszym artykule sformułowana została teza o istnieniu naturalnego prawa człowieka do bezpieczeństwa. Następnie przeanalizowany został problem relacji pomiędzy naturalnym prawem człowieka do bezpieczeństwa a bezpieczeństwem jako konstytucyjnym prawem człowieka. Podstawowym celem badawczym było udzielenie odpowiedzi na pytanie: Czy naturalne prawo człowieka do bezpieczeństwa znajduje przełożenie na istnienie bezpieczeństwa jako prawa człowieka, gwarantowanego przez prawo pozytywne, w tym przede wszystkim prawo konstytucyjne?

Analiza przepisów Konstytucji RP wykazała, że prawo do bezpieczeństwa jako konstytucyjne prawo człowieka nie zostało expressis verbis wyrażone w żadnym z tych przepisów. Zapewne sformułowanie wprost konstytucyjnego prawa człowieka do bezpieczeństwa rodzi obawy o zakres możliwości egzekwowania od państwa tego prawa przez obywatela, np. za pomocą skargi konstytucyjnej.

Niezależnie od podniesionych trudności warto wyinterpretować konstytucyjne prawo człowieka do bezpieczeństwa z całokształtu unormowań Konstytucji RP jako funkcje praw podstawowych. W uzasadnionych indywidualnych przypadkach naruszeń można konstytucyjne prawo człowieka do bezpieczeństwa wyprowadzać z art. 30 Konstytucji RP, który stanowi, że przyrodzona i niezbywalna godność człowieka jest źródłem jego praw i wolności.

Słowa kluczowe: bezpieczeństwo, prawo naturalne, prawo pozytywne, naturalne prawo człowieka do bezpieczeństwa, konstytucyjne prawo człowieka do bezpieczeństwa

\section{ЕСТЕСТВЕННОЕ ПРАВО ЧЕЛОВЕКА НА БЕЗОПАСНОСТЬ И БЕЗОПАСНОСТЬ КАК КОНСТИТУЦИОННОЕ ПРАВО ЧЕЛОВЕКА}

\section{Резюме}

В данной статье сформулирован тезис о существовании естественного права человека на безопасность. Затем была проанализирована проблема взаимосвязи между естественным правом человека на безопасность и безопасностью как конституционным правом человека. Основная цель исследования состояла в том, чтобы ответить на вопрос: трансформируется ли естественное право человека на безопасность в существование безопасности как права человека, гарантированного позитивным правом, особенно конституционным правом? 
Анализ положений Конституции Польши показал, что право на безопасность как конституционное право человека не было выражено expressis verbis ни в одном из этих положений. Безусловно, четкая формулировка конституционного права человека на безопасность вызывает опасения по поводу объема возможностей для гражданина реализовать это право от государства, например, посредством конституционной жалобы.

Независимо от поднятых трудностей, стоит интерпретировать конституционное право человека на безопасность, исходя из всех положений Конституции Польши, как функцию основных прав. В отдельных оправданных случаях нарушений конституционное право человека на безопасность вытекает из ст. 30 Конституции Польши, в которой говорится, что неотъемлемое достоинство человека является источником прав и свобод человека.

Ключевые слова: безопасность, естественное право, позитивное право, естественное право человека на безопасность, конституционное право человека на безопасность 
